\title{
CARCASS CHARACTERISTICS OF BROILERS AT 42 DAYS RECEIVING DIETS WITH PHYTASE IN DIFFERENT ENERGY AND CRUDE PROTEIN LEVELS ${ }^{1}$
}

\author{
Características de carcaça de frangos aos 42 dias recebendo rações \\ com fitase em diferentes níveis energéticos e de proteína bruta ${ }^{1}$
}

\author{
Adriano Kaneo Nagata ${ }^{2}$, Paulo Borges Rodrigues ${ }^{3}$, Renata Ribeiro Alvarenga ${ }^{4}$, \\ Márcio Gilberto Zangeronimo ${ }^{5}$, Daniella Carolina Zanardo Donato ${ }^{6}$, José Humberto Vilar da Silva ${ }^{7}$
}

\begin{abstract}
The aim of this study was to evaluate carcass characteristics and quality of breast meat after the inclusion of phytase in broiler diets with different levels of apparent metabolizable energy (AMEn) corrected for nitrogen and reduced crude protein (CP) supplemented with essential amino acids following the concept of ideal protein. A total of 1,500 Cobb broilers from 22 to 42 days (initial weight of 833 $\pm 7 \mathrm{~g}$ and final weight of $2741 \pm 48 \mathrm{~g}$ ) were distributed in completely randomized design in a factorial $3 \times 3+1$ experiment (three levels of AMEn - 2,950; 3,100 and 3,250 kcal/kg - and three levels of CP - 14, 16 and $18 \%$ - and an additional treatment - control without phytase, with 3,100 kcal/kg EMAn, 19.2\% PB and $0.4 \%$ available phosphorus), in six replications of 25 birds each. At the end of the trial, two birds of each experimental unit were slaughtered in order to measure carcass yield and yields of parts and to determine the chemical composition of the breast meat. The levels of AMEn and CP of diets with phytase influenced $(\mathrm{P}<0.05)$ the carcass, breast and abdominal fat yield and humidity, protein and fat percentage in the pectoralis major muscle of the birds. The levels of 3,100 kcal AMEn/ $\mathrm{kg}$ and $18 \% \mathrm{CP}$ showed higher carcass and breast yield and lower abdominal fat deposition, although with higher fat percentage in the breast meat. It was concluded that the manipulation of the energy levels of diets with reduced crude protein supplemented with amino acids and phytase influenced the yields of parts of carcass and the breast meat quality of the broilers at 42 days.
\end{abstract}

Index terms: Available phosphorus, dietary addictive, enzyme, ideal protein.

\section{RESUMO}

Objetivou-se, com este trabalho, estudar as características de carcaça e qualidade da carne do peito depois da inclusão de fitase em dietas para frangos de corte, com diferentes níveis de energia metabolizável aparente corrigida para nitrogênio (EMAn) e proteína bruta (PB) reduzida, suplementadas com aminoácidos essenciais seguindo o conceito de proteína ideal. Foram utilizados 1.500 frangos machos Cobb dos 22 aos 42 dias de idade com peso inicial de $833 \pm 7$ g e final de $2741 \pm 48$ g distribuídos em delineamento inteiramente casualizado em esquema fatorial 3x3+1 (três níveis de EMAn - 2950, 3100 e $3250 \mathrm{kcal} / \mathrm{kg}$ - e três de PB - 14, 16 e $18 \%$ e um tratamento adicional - controle, sem fitase, com $3100 \mathrm{kcal} / \mathrm{kg}$ EMAn, 19,2\% de PB e 0,4\% de fósforo disponível) em seis repetições com 25 aves cada. Ao final do experimento, duas aves de cada parcela foram sacrificadas para a mensuração do rendimento de carcaça e de cortes e determinação da composição química da carne do peito. Os níveis de energia e proteína em rações com fitase influenciaram $(\mathrm{P}<0,05)$ os rendimentos de carcaça, peito e gordura abdominal a porcentagem de umidade, proteína e lipídios no

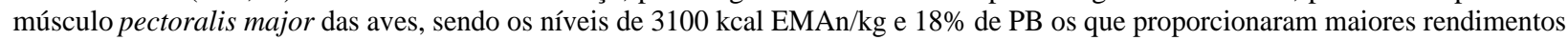
de carcaça e de peito e menor deposição de gordura abdominal, mas em maior teor de lipídios na carne do peito. Conclui-se que a manipulação da energia em rações com reduzido teor de proteína e suplementadas com aminoácidos e fitase influencia o rendimento de cortes e a qualidade da carne do peito de frangos aos 42 dias.

Termos para indexação: Fósforo disponível, aditivo, enzimas, proteína ideal.

(Received in july 4, 2010 and approved in november 11, 2010)

\section{INTRODUCTION}

Genetic improvement in chickens has directed the production of birds for better performance and greater carcass and cut yields. However, some other factors such as nutrition are also important in this context. The study of optimum balancing of diets for broilers contributes for the success of improvement programs, allowing animals to express their maximal genetic capacity. At the same time,

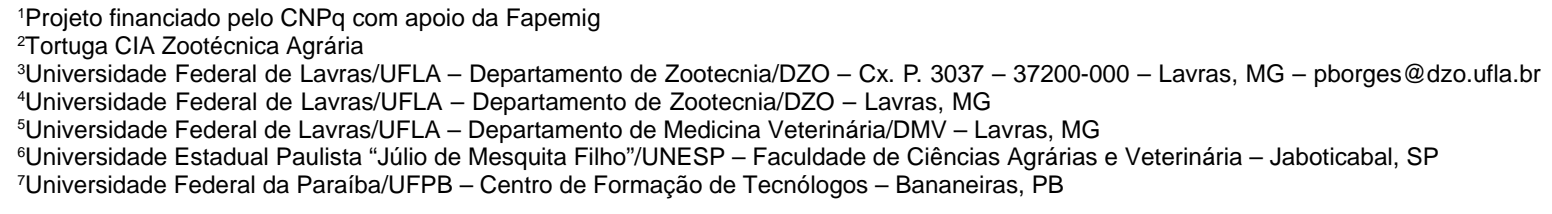


optimal diets may reduce costs with nutrition, improve the income and processing of carcass and still offer a better quality product to the final consumer.

Currently, several addictives have been used in diets of broilers in order to improve the utilization of nutrients (Pucci et al., 2010). Phytase, has a well known effect enhancing the use of the phytic phosphorus from feeds (Laurentiz et al., 2009). Thus, it allows the reduction of this element during the elaboration of the diets. However, it was reported that the inclusion of this enzyme can also increase availability of amino acids (Ravindran et al., 2000), some ions (Maenz, 2001) and starch (Angel et al., 2002). These properties may be able to compromise the amino acid and electrolyte balance, especially in diets elaborated following the ideal protein concept.

The carcass and cuts yields and the quality of final product offered to the consumer could be influenced by the unbalance between the main essential nutrients and its relationships with the energy levels of the diets. It is known that the definition of excellent levels of energy in started diets is important, since the actual broilers strains have more specific nutritional requirements. When the bird ingests energy above of its metabolic needs, the deposition of fat in the carcass occurs, most of it in the abdominal region (Summers \& Leeson, 1979). This deposition can be a result of the high relationship energy:crude protein of the diet or unbalance of amino acids. Moreover, the use of diets elaborated using the ideal protein concept has been related to a higher accumulation of fat by the animals, despite the lower amount of energy needed to metabolize the excess of amino acid (Sklan \& Plavnik, 2002).

Studies evaluating the reduction of crude protein in diets with crystalline amino acid inclusion in order to improve the use of nutrients (especially nitrogen) and the inclusion of phytase to reduce the phosphorus released by birds are needed particularly with regard to the energy levels on the diets.

Thus, the aim of this study was to evaluate carcass characteristics and quality of breast meat from broilers fed diets with phytase, different levels of nitrogen-corrected apparent metabolizable energy (AMEn) and reduced crude protein $(\mathrm{CP})$ supplemented with aminoacids.

\section{MATERIAL AND METHODS}

The experiment was lead in the Poultry Sector of the Animal Science Department of the Federal University of Lavras (UFLA), in Lavras, MG, Brazil.

One thousand and five hundred male Cobb 500 broilers from 22 to 42 days of age (initial weight: $833 \pm 7 \mathrm{~g}$ and final weight: $2,741 \pm 48 \mathrm{~g}$ ) were randomly distributed in 60 boxes. Water and feed had been supplied ad libitum during the experimental period.

Birds were distributed randomly in a factorial experiment $3 \times 3+1$ (three levels of nitrogen-correct apparent metabolizable energy - 2,950; 3,100 and 3,250 $\mathrm{kcal} / \mathrm{kg}$ - and three levels of crude protein - 14, 16 and $18 \%$ - and additional control treatment, without phytase), totalizing ten treatments with six repetitions of 25 birds each. The additional treatment (control) was elaborated to attend the nutritional recommendations of Rostagno et al. (2000).

The experimental diets were formulated based on corn and soybean meal and, except the control diet, the other treatments were formulated in digestible amino acids basis, following the minimum recommendations suggested by Rostagno et al. (2005) for broilers from 22 to 42 days of age (Table 1). In exception of the control diet, was all diets were added 500 PTU of phytase $/ \mathrm{kg}$ (Ronozyme - $5000 \mathrm{PTU} / \mathrm{g}$ ), reducing the available phosphorus from $0.40 \%$ to $0.31 \%$ and calcium from $0.89 \%$ to $0.71 \%$.

At the end of the experimental period, two birds of each experimental unit were selected considering the individual weight corresponding to the average of the group, submitted to eight hours of fasting and slaughtered. Following, feather and viscera were removed and the carcasses (without head, feet and abdominal fat) were weighed. Breast, drumstick, tigh and the abdominal fat were also weighed. The carcass yield was calculated using the carcass weight and the live weight after fasting. The cut yields were obtained dividing the gross weight of the animals by the carcass weight.

Two breasts of each treatment were randomly separated, packed in plastic bags and stored frozen until analysis. After defrost, skin, fat and bone were removed and the muscles were triturated in a multiprocessor until a homogeneous mass was obtained. A sample was used to determine humidity, protein, fat and ashes in duplicate, following AOAC Methods (Association of Official Analytical Chemistry - AOAC, 1995).

The carcass and parts yields, the abdominal fat and the composition analysis of breast meat (humidity, protein, fat and ashes) were evaluated. A global analysis of variance was made with all the treatments, aiming to get the residue average square to test the factorial and to apply the Dunnet test at 5\%, comparing the control treatment against the others. To compare the factorial treatments, the SNK test was used at $5 \%$. All the statistical analyses were made using the software SISVAR (Ferreira, 2000). 
Table 1 - Percentual composition of the experimental diets.

\begin{tabular}{|c|c|c|c|c|c|c|c|c|c|c|}
\hline \multirow{2}{*}{ Ingredient } & \multirow{2}{*}{$\begin{array}{c}\text { Control } \\
\text { diet }\end{array}$} & \multicolumn{3}{|c|}{$14 \% \mathrm{CP}$ diets } & \multicolumn{3}{|c|}{$16 \% \mathrm{CP}$ diets } & \multicolumn{3}{|c|}{$18 \% \mathrm{CP}$ diets } \\
\hline & & $2,950^{1}$ & 3,100 & 3,250 & 2,950 & 3,100 & 3,250 & 2,950 & 3,100 & 3,250 \\
\hline Corn & 61.70 & 73.10 & 73.10 & 73.10 & 68.80 & 68.80 & 68.80 & 63.30 & 63.30 & 63.30 \\
\hline Soybean meal & 30.53 & 16.90 & 16.9 & 16.90 & 22.20 & 22.20 & 22.20 & 27.62 & 27.62 & 27.62 \\
\hline Kaulim & 0.404 & 4.024 & 2.344 & 0.644 & 3.554 & 1.844 & 0.134 & 3.584 & 1.884 & 0.184 \\
\hline Bicalcium phosphate & 1.58 & 1.20 & 1.20 & 1.20 & 1.17 & 1.17 & 1.17 & 1.10 & 1.10 & 1.10 \\
\hline Soybean oil & 3.74 & 1.20 & 2.88 & 4.58 & 1.45 & 3.16 & 4.87 & 2.18 & 3.88 & 5.58 \\
\hline Limestone & 1.02 & 0.86 & 0.86 & 0.86 & 0.84 & 0.84 & 0.84 & 0.84 & 0.84 & 0.84 \\
\hline Salt & 0.48 & 0.48 & 0.48 & 0.48 & 0.48 & 0.48 & 0.48 & 0.48 & 0.48 & 0.48 \\
\hline L-lysine $\mathrm{HCl} 79 \%$ & 0.18 & 0.61 & 0.61 & 0.61 & 0.45 & 0.45 & 0.45 & 0.30 & 0.30 & 0.30 \\
\hline DL-methionine $99 \%$ & 0.20 & 0.33 & 0.33 & 0.33 & 0.28 & 0.28 & 0.28 & 0.24 & 0.24 & 0.24 \\
\hline L-valine & - & 0.28 & 0.28 & 0.28 & 0.20 & 0.20 & 0.20 & 0.11 & 0.11 & 0.11 \\
\hline L-arginine & - & 0.36 & 0.36 & 0.36 & 0.21 & 0.21 & 0.21 & 0.05 & 0.05 & 0.05 \\
\hline L-threonine & - & 0.13 & 0.13 & 0.13 & 0.07 & 0.07 & 0.07 & - & - & - \\
\hline L-isoleucine & - & 0.21 & 0.21 & 0.21 & 0.12 & 0.12 & 0.12 & 0.02 & 0.02 & 0.02 \\
\hline L-tryptophan & - & 0.05 & 0.05 & 0.05 & - & - & - & - & - & - \\
\hline L-phenylalanine & - & 0.09 & 0.09 & 0.09 & - & - & - & - & - & - \\
\hline Vitamin $\operatorname{mix}^{2}$ & 0.035 & 0.035 & 0.035 & 0.035 & 0.035 & 0.035 & 0.035 & 0.035 & 0.035 & 0.035 \\
\hline Mineral $\operatorname{mix}^{3}$ & 0.05 & 0.05 & 0.05 & 0.05 & 0.05 & 0.05 & 0.05 & 0.05 & 0.05 & 0.05 \\
\hline Coline chloride $60 \%$ & 0.05 & 0.05 & 0.05 & 0.05 & 0.05 & 0.05 & 0.05 & 0.05 & 0.05 & 0.05 \\
\hline Salinomicin $12 \%$ & 0.021 & 0.021 & 0.021 & 0.021 & 0.021 & 0.021 & 0.021 & 0.021 & 0.021 & 0.021 \\
\hline Bacitracin zinc & 0.01 & 0.01 & 0.01 & 0.01 & 0.01 & 0.01 & 0.01 & 0.01 & 0.01 & 0.01 \\
\hline Phytase $^{4}$ & - & 0.01 & 0.01 & 0.01 & 0.01 & 0.01 & 0.01 & 0.01 & 0.01 & 0.01 \\
\hline \multicolumn{11}{|l|}{ Calculated values } \\
\hline Crude protein $(\%)$ & 19.2 & 14.0 & 14.0 & 14.0 & 16.0 & 16.0 & 16.0 & 18.0 & 18.0 & 18.0 \\
\hline AMEn (kcal/kg) & 3100 & 2950 & 3100 & 3250 & 2950 & 3100 & 3250 & 2950 & 3100 & 3250 \\
\hline Calcium (\%) & 0.90 & 0.70 & 0.70 & 0.70 & 0.70 & 0.70 & 0.70 & 0.70 & 0.70 & 0.70 \\
\hline Available phosphorus (\%) & 0.40 & 0.31 & 0.31 & 0.31 & 0.31 & 0.31 & 0.31 & 0.31 & 0.31 & 0.31 \\
\hline Digestible lysine (\%) & 1.04 & 1.05 & 1.05 & 1.05 & 1.05 & 1.05 & 1.05 & 1.06 & 1.06 & 1.06 \\
\hline Methionine + Cystine $(\%)$ & 0.74 & 0.75 & 0.75 & 0.75 & 0.75 & 0.75 & 0.75 & 0.75 & 0.75 & 0.75 \\
\hline Digestible threonine (\%) & 0.65 & 0.59 & 0.59 & 0.59 & 0.61 & 0.61 & 0.61 & 0.61 & 0.61 & 0.61 \\
\hline $\begin{array}{l}\text { Digestible thryptophan } \\
(\%)\end{array}$ & 0.21 & 0.19 & 0.19 & 0.19 & 0.17 & 0.17 & 0.17 & 0.20 & 0.20 & 0.20 \\
\hline Digestible isoleucine (\%) & 0.74 & 0.72 & 0.72 & 0.72 & 0.72 & 0.72 & 0.72 & 0.71 & 0.71 & 0.71 \\
\hline Digestible arginine (\%) & 1.18 & 1.15 & 1.15 & 1.15 & 1.16 & 1.16 & 1.16 & 1.15 & 1.15 & 1.15 \\
\hline Digestible valine (\%) & 0.79 & 0.85 & 0.85 & 0.85 & 0.86 & 0.86 & 0.86 & 0.85 & 0.85 & 0.85 \\
\hline $\begin{array}{l}\text { Digestible } \\
\text { phenylalanine (\%) }\end{array}$ & 0.87 & 0.71 & 0.71 & 0.71 & 0.72 & 0.72 & 0.72 & 0.81 & 0.81 & 0.81 \\
\hline
\end{tabular}

${ }^{1} \mathrm{kcal}$ of nitrogen corrected metabolizable energy (AMEn/kg) of dry matter;

${ }^{2}$ Supplied by kilo of diet: $6,0 \mathrm{mg}$ vitamin $\mathrm{B}_{12} ; 12.000 \mathrm{UI}$ vitamin $\mathrm{A} ; 2.200$ UI vitamin $\mathrm{D}_{3} ; 53,0 \mathrm{mg}$ nicotinamide; $2,2 \mathrm{mg}$ vitamin $\mathrm{B}_{1}$; $3,3 \mathrm{mg}$ vitamin $\mathrm{B}_{6} ; 16,0$ mcg vitamin $\mathrm{B}_{12} ; 0,11 \mathrm{mg}$ biotin; $1,0 \mathrm{mg}$ folic acid; $130 \mathrm{mg}$ pantothenic acid; $2,5 \mathrm{mg}$ vitamin $\mathrm{K}_{3} ; 30 \mathrm{mg}$ vitamin $\mathrm{E} ; 120 \mathrm{mg}$ antioxidant;

${ }^{3}$ Supplied by kilo of diet: $60 \mathrm{mg}$ of zinc; $30 \mathrm{mg}$ of iron; $9 \mathrm{mg}$ of cupper; $60 \mathrm{mg}$ manganese; 1,0 mg iodine;

${ }^{4} 5000 \mathrm{PTU} / \mathrm{g}$ of diet. 


\section{RESULTS AND DISCUSSION}

Comparing the control diet whit the others (Table 2), it was observed that there was no difference $(\mathrm{P}>0.05)$ in the carcass, breast and thigh + drumstick yield, which means that the addition of phytase in the diets with reduced crude protein and different energy levels did not influence these parameters, however affected $(\mathrm{P}<0.05)$ the abdominal fat yield. In this case, the reduction of crude protein from $19 \%$ (control) to $14 \%$ and the addition of the enzyme increased the abdominal fat deposition $(\mathrm{P}<0.05)$ in all energy levels studied.

Working with phytase in diets for broilers, Brandão et al. (2007) verified no effect of the enzyme in carcass, breast and abdominal fat yield. However, considering the reduction of the crude protein in the diets, Faria Filho et al. (2005) verified that the reduction from 21.5 to $18.5 \%$ decreased the breast yield and increased the abdominal fat of the birds at 21 days of age. Nevertheless, Gomide et al. (2007) did not observe effect of the reduction of dietary crude protein on breast and carcass yields. However, they observed a reduction in the thigh + drumstick and increase of the abdominal fat yields. According to Leenstra (1989), the excess of fat deposition in the carcass is harmful for the broiler production. Therefore, the fat is considered inconvenient by the consumer and it may represent loss in the carcass yield during the industrialization process.

This variation in the results can be explained, in part, by genetic variability observed in the different research protocols (Marcato et al., 2009), different types of diet compositions (Costa et al., 2007) and by amino acids, calcium and phosphorus levels in the diets (Silva et al., 2008), moreover the environment conditions.

According to Fischer (1994), in conditions of nutritional deficiency, mainly of essential amino acids, the breast muscle can be affected. In the present study, the breast yield was not influenced by dietary crude protein levels, compared to control. This suggests that the amino acid inclusion was satisfactory, keeping the muscle growth of the breast. Similar results were found by Sabino et al. (2004), when reducing the crude protein from 23 to $15 \%$.

However, the higher accumulation of abdominal fat by the birds that received $14 \% \mathrm{CP}$ diets can be explained by the lower level of energy used for degradation of the amino acid excess, contributing with extra energy and the storage in the fat cells (Sklan \& Plavnik, 2002).

Considering the phytase treatments, it was observed an interaction $(\mathrm{P}<0.05)$ between the energy and protein levels for the breast and carcass yields. However, these levels had no effect on the thigh + drumstick yield $(\mathrm{P}>0.05)$. Only the crude protein levels influenced $(\mathrm{P}<0.05)$ the abdominal fat.
In $16 \% \mathrm{CP}$ diets, supplemented with amino acids and phytase, the energy levels did not influence the carcass yield. However in $18 \%$ CP treatments, the level that kept the best response was $3,100 \mathrm{kcal} / \mathrm{kg}$ of metabolizable energy. Nevertheless, when the protein was reduced to $14 \% \mathrm{CP}$ by the addition of phytase, the energy level might be kept in 3,100 or risen to $3,250 \mathrm{kcal} / \mathrm{kg}$.

Table 2 - Carcass and cut yields of broilers at 42 days of age.

\begin{tabular}{|c|c|c|c|c|}
\hline \multirow{2}{*}{ AMEn $(\mathrm{kcal} / / \mathrm{kg})$} & \multicolumn{3}{|c|}{ Crude protein } & \multirow{2}{*}{ Average } \\
\hline & 14 & 16 & 18 & \\
\hline \multicolumn{5}{|c|}{ Carcass yield (\%) } \\
\hline 2,950 & $71.1^{\mathrm{B}}$ & 72.2 & $72.5^{\mathrm{AB}}$ & 72.0 \\
\hline 3,100 & $72.1^{\mathrm{AB}}$ & 72.1 & $73.8^{\mathrm{A}}$ & 72.7 \\
\hline 3,250 & $73.1^{\mathrm{a}}$ & 71.8 & $71.6^{\mathrm{B}}$ & 72.2 \\
\hline Average & 72.1 & 72.0 & 72.7 & 72.3 \\
\hline Control & 72.3 & & & \\
\hline $\mathrm{CV}(\%)$ & 1.83 & & & \\
\hline \multicolumn{5}{|c|}{ Breast yield (\%) } \\
\hline 2,950 & 32.0 & 32.8 & $33.3^{\mathrm{A}}$ & 32.7 \\
\hline 3,100 & $31.2^{\mathrm{b}}$ & $32.2^{\mathrm{b}}$ & $33.9^{\mathrm{aA}}$ & 32.4 \\
\hline 3,250 & 31.9 & 32.5 & $31.9^{\mathrm{B}}$ & 32.1 \\
\hline Average & 31.7 & 32.5 & 33.0 & 32.4 \\
\hline Control & 32.3 & & & \\
\hline $\mathrm{CV}(\%)$ & 2.96 & & & \\
\hline \multicolumn{5}{|c|}{ Thigh + drumstick yield $(\%)$} \\
\hline 2,950 & 27.6 & 27.7 & 27.7 & 27.7 \\
\hline 3,100 & 28.3 & 27.4 & 27.4 & 27.7 \\
\hline 3,250 & 27.3 & 28.0 & 27.8 & 27.7 \\
\hline Average & 27.7 & 27.7 & 27.6 & 27.7 \\
\hline Control & 26.9 & & & \\
\hline $\mathrm{CV}(\%)$ & 3.01 & & & \\
\hline \multicolumn{5}{|c|}{ Abdominal fat (\%) } \\
\hline 2,950 & $1.60 *$ & 1.21 & 1.11 & 1.30 \\
\hline 3,100 & $1.53 *$ & 1.28 & 1.10 & 1.30 \\
\hline 3,250 & $1.62 *$ & 1.32 & 1.17 & 1.37 \\
\hline Average & $1.58^{\mathrm{a}}$ & $1.27^{\mathrm{b}}$ & $1.13^{\mathrm{b}}$ & 1.32 \\
\hline Control & 1.10 & & & \\
\hline $\mathrm{CV}(\%)$ & 18.79 & & & \\
\hline
\end{tabular}

* Means differ from the control diet by Dunnet test $(\mathrm{P}<005)$. ${ }^{\text {abc }}$ Different small letters in the same line differ by SNK test $(\mathrm{P}<0.05)$. ${ }^{\mathrm{ABC}}$ Different capital letters in the same column differ by SNK test $(\mathrm{P}<0.05)$. 
The carcass yield can be related to two factors: the muscle or the visceral growth. According to the present results of the cuts, it was suggested a change in the visceral mass in 14 and $18 \%$ CP diets. The excess or deficiency of energy could have increased the visceral mass, in the attempt to balance the energy:nutrient levels.

For the breast yield, the metabolizable energy of the diets influenced $(\mathrm{P}<0.05)$ the values only in $18 \% \mathrm{CP}$ diets. Differences were not observed $(\mathrm{P}>0.05)$ when 16 or $14 \% \mathrm{CP}$ were used. The protein levels were significant $(\mathrm{P}<0.05)$ only in diets with $3,100 \mathrm{kcal} / \mathrm{kg}$ of corrected apparent metabolizable energy. In this case, the higher quantity of nutrients granted by the higher crude protein (18\%) resulted in higher cut yields. These data are similar to those presented by Leeson (1995) who affirmed that the breast yield increases with the increase of protein consumption.

The higher breast yield resulted by $18 \% \mathrm{CP}$ diets were found with 3,100 or $2,950 \mathrm{kcal} / \mathrm{kg}$ of metabolizable energy. This result can be probably related to the higher consumption and, consequently, to the greater amount of nutrients, warranting more intense breast muscle growth.

The energy levels in the diets did not influence the abdominal fat $(\mathrm{P}>0.05)$. However, the reduction of protein to $14 \%$ increased $(\mathrm{P}<0.05)$ the fat deposition in the broilers. These results are in accordance to Faria Filho et al. (2005) that worked with diets without phytase. Considering the inclusion of this enzyme and addition the majority of essential amino acids for broilers, the animals presented increased fat storage when the diets had excessively reduced crude protein.

With regard to the chemical composition of the breast meat (Table 3), comparing the control diet with the others containing phytase and reduced crude protein in different energy levels, it was observed that these values were similar to the majority of the comparative averages. Birds that ingested $18 \% \mathrm{CP}$ diets and 3,250 or 2,950 kcal ME/kg presented lower humidity values with regard to the control diet. This result can be explained by the higher deposition of other chemical components (proteins, lipids, minerals and carbohydrates).

It was also observed $(\mathrm{P}<0.05)$ a higher percentage of lipids in breast meat from birds that received diets with $14 \% \mathrm{CP}$ and $3,250 \mathrm{kcal} / \mathrm{kg}$ or with $18 \% \mathrm{CP}$ and 3,200 or $3,100 \mathrm{kcal} \mathrm{ME} / \mathrm{kg}$. These results can be due to the higher energy level available to the fat synthesis in the cut.

It is well known that the phytase acts breaking the phytic acid and discharging the phosphorus and other nutrients, allowing better assimilation by animals. Because there was a reduction of the phosphorus in diets containing phytase, the results showed that the enzyme acted efficiently, keeping the same quantity of ashes in the breast meat.
There was a significant interaction $(\mathrm{P}<0.05)$ between the energy and protein in the diet for all chemical composition variables of evaluated breast meat, except the ash percentage $(\mathrm{P}>0.05)$, where no effect was observed.

Table 3 - Composition of breast meat chest from broilers at 42 days of age.

\begin{tabular}{|c|c|c|c|c|}
\hline \multirow{2}{*}{ AMEn (kcal//kg) } & \multicolumn{3}{|c|}{ Crude protein } & \multirow{2}{*}{ Average } \\
\hline & 14 & 16 & 18 & \\
\hline \multicolumn{5}{|c|}{ Humidity (\%) } \\
\hline 2,950 & $74.2^{\mathrm{b}}$ & $74.9^{\mathrm{a}}$ & $74.1 *^{\mathrm{bB}}$ & 74.4 \\
\hline 3,100 & 74.8 & 74.7 & $75.5^{\mathrm{A}}$ & 75.0 \\
\hline 3,250 & 74.7 & 74.7 & $74.1 *^{\mathrm{B}}$ & 74.4 \\
\hline Average & 74.5 & 74.7 & 74.5 & \\
\hline Control & 75.2 & & & \\
\hline $\mathrm{CV}(\%)$ & 0.93 & & & \\
\hline \multicolumn{5}{|c|}{ Protein (\%) } \\
\hline 2,950 & $24.5^{\mathrm{aA}}$ & $23.0^{\mathrm{b}}$ & $24.1^{\mathrm{aA}}$ & 23.9 \\
\hline 3,100 & $23.8^{\mathrm{aAB}}$ & $22.6^{\mathrm{b}}$ & $22.4^{\mathrm{bB}}$ & 22.9 \\
\hline 3,250 & $23.1^{\mathrm{bB}}$ & $23.0^{\mathrm{b}}$ & $24.3^{\mathrm{aA}}$ & 23.5 \\
\hline Average & 23.8 & 23.0 & 23.6 & \\
\hline Control & 23.4 & & & \\
\hline $\mathrm{CV}(\%)$ & 3.32 & & & \\
\hline \multicolumn{5}{|c|}{ Lipids (\%) } \\
\hline 2,950 & $1.24^{\mathrm{B}}$ & 1.24 & $1.13^{\mathrm{B}}$ & 1.20 \\
\hline 3,100 & $1.08^{\mathrm{bB}}$ & $1.19^{\mathrm{b}}$ & $1.52 *^{\mathrm{aA}}$ & 1.26 \\
\hline 3,250 & $1.55^{* \mathrm{aA}}$ & $1.25^{\mathrm{b}}$ & $1.31 * \mathrm{bB}$ & 1.37 \\
\hline Average & 1.29 & 1.23 & 1.32 & \\
\hline Control & 0.97 & & & \\
\hline $\mathrm{CV}(\%)$ & 16.30 & & & \\
\hline \multicolumn{5}{|c|}{ Ashes (\%) } \\
\hline 2,950 & 0.98 & 0.94 & 1.03 & 0.98 \\
\hline 3,100 & 0.99 & 1.03 & 0.98 & 1.00 \\
\hline 3,250 & 1.00 & 0.99 & 0.99 & 1.00 \\
\hline Average & 0.99 & 0.98 & 1.00 & \\
\hline Control & 0.98 & & & \\
\hline $\mathrm{CV}(\%)$ & 7.88 & & & \\
\hline
\end{tabular}

* Means differ from the control diet by Dunnet test $(\mathrm{P}<005)$. ${ }^{a b c}$ Different small letters in the same line differ by SNK test $(\mathrm{P}<0.05)$.

${ }^{\mathrm{ABC}}$ Different capital letters in the same column differ by SNK test $(\mathrm{P}<0.05)$. 
Analyzing the effect of the crude protein on the humidity of breast meat, considering the diets with lower energy level $(2,950 \mathrm{kcal} / \mathrm{kg})$, it was observed that $16 \%$ of crude protein resulted $(\mathrm{P}<0.05)$ in greater values. However, raising the energy level, the same effect was not observed ( $P>0.05)$. This suggests that the metabolizable energy must be kept or be raised to assure the protein deposition in the muscles of birds consuming diets with reduced crude protein and supplemented with phytase.

There was an effect of the energy levels only in $18 \% \mathrm{CP}$ diets, being 3,100 kcal ME/ $/ \mathrm{kg}$ the level that resulted $(\mathrm{P}<0.05)$ in higher humidity, which was not expected. This fact can be explained, probably, by the lower quantity of glycogen in the muscle of the birds.

The crude protein levels of the diets also influenced $(\mathrm{P}<0.05)$ the protein percentage in the breast meat. Unexpectadly, in diets with lower energy level, the birds that received 14 and $18 \% \mathrm{CP}$ diets showed higher protein deposition. However, keeping diets with recommended $3,100 \mathrm{kcal}$ of $\mathrm{ME} / \mathrm{kg}$, it was observed higher protein synthesis in birds that were fed diets with $14 \%$ of crude protein. These results contradict Leeson (1995) that observed reduction on the protein deposition on breast meat from birds with reduced dietary protein level, when comparing diets with reduced crude protein levels and supplemented or not with lysine and methionine. It is important to emphasize that, in this case, only two amino acids were added. Thus, these results can be linked to the lack of limited amino acids. In the present work, the most favorable amino acids ratio could have favored the high protein percentage found in the breast meat of the birds.

Otherwise, the birds that were fed diets with 3,250 $\mathrm{kcal} \mathrm{ME} / \mathrm{kg}$ showed $(\mathrm{P}<0.05)$ higher breast meat protein when receiving $18 \% \mathrm{CP}$ diets. This can be related to the lower consumption by the birds that received diets with this energy level. In this case, the greater protein supply could explain these results.

When the dietary energy level effect was compared, $14 \%$ CP diets produced higher protein synthesis in the breast meat from birds that consumed diets with $2,950 \mathrm{kcal}$ $\mathrm{ME} / \mathrm{kg}$. However, raising the protein level to $18 \%$, the 3,100 $\mathrm{kcal} \mathrm{ME} / \mathrm{kg}$ was the energy level that showed better result. This can be also related to the diet consumption, since the lower supplied energy by diets favor nutrients ingestion.

Unexpectedly, no effect was observed $(\mathrm{P}<0.05)$ for the dietary energy levels on the protein percentage in the breast meat of birds fed $16 \%$ CP diets.

With regard to fat percentage, in diets with reduced crude protein levels, the increase of the energy levels resulted $(\mathrm{P}<0.05)$ in higher fat deposition in the breast meat.
For $18 \% \mathrm{CP}$ diets, higher deposition was obtained with $3,100 \mathrm{kcal}$ of $\mathrm{ME} / \mathrm{kg}$. However, with $16 \%$ of crude protein, there was no effect $(\mathrm{P}>0.05)$ of the energy levels. When the dietary energy levels were $3,100 \mathrm{kcal}$ of $\mathrm{ME} / \mathrm{kg}$ with added phytase, the dietary protein level that resulted in higher fat percentage was $18 \%$. This can be explained by the higher supply of nutrients, mainly considering that phytase can increase partially their availability.

The present results can be considered controversial when considering the effect of phytase, the reduction of crude protein and the manipulation of energy levels of the diets. More studies are needed to evaluate the real requirements of the animals raised in different situations and, at the same time, to verify the effect of phytase on the availability of these nutrients for the birds in order to ensure higher cut yields and better quality of the chicken.

\section{CONCLUSIONS}

The manipulation of metabolizable energy levels in diets with reduced crude protein, available phosphorus and calcium supplemented with amino acids and phytase influenced cut yields and the quality of breast meat from broilers at 42 days of age. For higher carcass and breast yields lower deposition of abdominal fat with higher fat percentage in the breast meat, it is recommended diets with $3,100 \mathrm{kcal}$ of $\mathrm{ME} / \mathrm{kg}$ and $18 \%$ of crude protein.

\section{REFERENCES}

ANGEL, R.; TAMIM, N.M.; APPLEGATE, T.J.; DHANDU, A.S.; ELLESTAD, L.E. Phytic acid chemistry: influence on phytin-phosphorus availability and phytase efficacy. Journal of Applied Poultry Research, Athens, v.11, n.4, p.471-480, 2002.

\section{ASSOCIATION OF OFFICIAL ANALYTICAL CHEMISTS. Official methods of analysis. 14.ed. Washington, 1995.}

BRANDÃO, P.A.; COSTA, P.G.P.; BRANDÃO, J.S.; SILVA, J.H.V. Efeito da adição de fitase em rações de frangos de corte, durante as fases de crescimento e final. Ciência e Agrotecnologia, Lavras, v.31, n.2, p.492-498, 2007.

COSTA, F.G.P.; BRANDÃO, P.A.; BRANDÃO, J.S.; SILVA, J.H.V. Efeito da enzima fitase nas rações de frangos de corte, durante as fases pré-inicial e inicial. Ciência e Agrotecnologia, Lavras, v.31, n.3, p.865-870, 2007. 
FARIA FILHO, D.E.; ROSA, P.S.; VIEIRA, B.S.; MACARI, M.; FURLAN, R.L. Protein levels and environmental temperature effects on carcass characteristics, performance, and nitrogen excretion of broiler chickens from 7 to 21 days of age. Revista Brasileira de Ciência Avícola, São Paulo, v.7, n.4, p.247253, 2005.

FERREIRA, D.F. Análises estatísticas por meio do SISVAR para Windows versão 4.0. In: REUNIÃO ANUAL DA REGIÃO BRASILEIRA DA SOCIEDADE INTERNACIONAL DE BIOMETRIA, 45., 2000, São Carlos. Anais... São Carlos: UFSCar, 2000. p.255-258.

FISCHER, C. Use of amino acids to improve carcass quality of broilers. Feed Mix, v.2, p.17-20, 1994.

GOMIDE, E.M.; RODRIGUES, P.B.; FREITAS, R.T.F.; FIALHO, E.T. Planos nutricionais com a utilização de aminoácidos e fitase para frangos de corte mantendo o conceito de proteína ideal nas dietas. Revista Brasileira de Zootecnia, Viçosa, v.36, n.6, p.1769-1774, 2007.

LAURENTIZ, A.C.; JUNQUEIRA, O.M.; FILARDI, R.S.; DUARTE, K.F.; ASSUENA, V.; SGAVIOLI, S.

Desempenho, composição da cama, das tíbias, do fígado e das excretas de frangos de corte alimentados com rações contendo fitase e baixos níveis de fósforo.

Revista Brasileira de Zootecnia, Viçosa, v.38, n.10, p.1938-1947, 2009.

LEENSTRA, F.R. Influence of diet and genotype on carcass quality in poultry, and their consequences for selection. In: COLE, D.J.A.; HARESIGN, W. (Eds.). Recent developments in poultry nutrition. London: Butterworths, 1989. p.131-44.

MAENZ, D.D. Enzymatic characteristics of phytases as they relate to their use in animals feeds. In: BEDFORD, M.R.; PARTRIDGE, G.G. (Eds.). Enzymes in farm animal nutrition. Wallingford: CAB, 2001.

MARCATO, S.M.; SAKOMURA, N.K.; FERNANDEZ, J.B.K.; NASCIMENTO, D.C.N.; FURLAN, R.L.; PIVA, G.H. Crescimento e deposição de nutrientes nas penas, músculo, ossos e pele de frangos de corte de duas linhagens comerciais. Ciência e Agrotecnologia, Lavras, v.33, n.4, p.1159-1168, 2009.

PUCCI, L.E.A.; RODRIGUES, P.B.; FREITAS, R.T.F.; FIALHO, E.T.; NASCIMENTO, G.A.J.do; ALVARENGA, R.R. Efeito do processamento, suplementação enzimática e nível nutricional da ração para frangos de corte no período de 22 a 42 dias de idade. Ciência e Agrotecnologia, Lavras, v. 34, n. 6, p. 1557 1565, Nov./dez., 2010.

RAVINDRAN, V.; CABAHUG, S.; RAVINDRAM, G.; BRYDEN, W.L.; SELLE, P.H. Response of broilers to microbial phytase supplementation as influenced by dietary phytic acid and non-phytate phosphorus levels: II., effects on nutrient digestibility and retention. British Poultry Science, Edinburg, v.41, n.2, p.193-200, 2000.

ROSTAGNO, H.S.; ALBINO, L.F.T.; DONZELE, J.L.; GOMES, P.C.; FERREIRA, A.S.; OLIVEIRA, R.F.; LOPES, D.C. Tabelas brasileiras para aves e suínos: composição de alimentos e exigências nutricionais. Viçosa, MG: UFV, 2000. 141p.

SABINO, H.F.; SAKOMURA, N.K.; NEME, R.; FREITAS E.R. Níveis protéicos na ração de frangos de corte na fase de crescimento. Pesquisa Agropecuária Brasileira, Brasília, v.39, n.5, p.407-412, 2004.

SILVA, Y.L.; RODRIGUES, P.B.; FREITAS, R.T.; ZANGERONIMO, M.G.; FIALHO, E.T. Níveis de proteína e fósforo em rações com fitase para frangos de corte, na fase de 14 a 21 dias de idade: 2., valores energéticos e digestibilidade de nutrientes. Revista Brasileira de Zootecnia, Viçosa, v.37, n.3, p.469-477, 2008.

SKLAN, D.; PLAVNIK, I. Interactions between dietary crude protein and essential amino acid intake on performance in broilers. British Poultry Science, London, v.43, p.442-449, 2002.

SUMMERS, J.D.; LEESON, S. Composition of poultry meat as affected by nutritional factors. Poultry Science, Champaign, v.58, p.536-542, 1979. 